\title{
Beta cell (dys)function in non-diabetic offspring of diabetic patients
}

\author{
M. Stadler • G. Pacini • J. Petrie • A. Luger • \\ C. Anderwald $\cdot$ on behalf of the RISC Investigators
}

Received: 14 May 2009/Accepted: 6 August 2009/Published online: 12 September 2009

(C) Springer-Verlag 2009

\begin{abstract}
Aims/hypothesis The first-degree offspring of patients with type 2 diabetes are prone to develop type 2 diabetes, and have both insulin resistance and beta cell impairment. However, it is still unclear whether both pathophysiological features are inseparably combined and which is the outstanding determinant in the offspring.

Methods Glucose metabolism, insulin sensitivity (calculated as $M$ value divided by insulin [M/I]) and beta cell function were studied in the offspring of individuals with type 2
\end{abstract}

Electronic supplementary material The online version of this article (doi:10.1007/s00125-009-1520-7) contains details of the RISC investigators as supplementary material which is available to authorised users.

\section{Stadler}

3rd Medical Department of Metabolic Diseases and Nephrology, Hietzing Hospital,

Vienna, Austria

\section{Stadler}

Karl Landsteiner Institute of Metabolic Diseases and Nephrology,

Vienna, Austria

G. Pacini

Metabolic Unit, Institute of Biomedical Engineering, ISIB-CNR,

Padova, Italy

\section{J. Petrie}

Section of Diabetes, Division of Medicine and Therapeutics, Ninewells Hospital and Medical School, University of Dundee, Dundee, UK

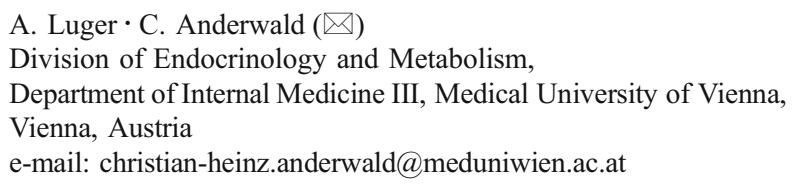

diabetes $(n=187 ; 57 \%$ females; age $43.8 \pm 8.1$ years; BMI $26.8 \pm 4.5 \mathrm{~kg} / \mathrm{m}^{2}$ ) and in individuals without a family history of type 2 diabetes (controls, $n=519,55 \%$ females; age $43.4 \pm 8.2$ years; BMI $26.4 \pm 3.7 \mathrm{~kg} / \mathrm{m}^{2}$, no significant differences between the groups for any characteristic) by performance of $75 \mathrm{~g}$ OGTT and $2 \mathrm{~h}$ hyperinsulinaemic $\left(40 \mathrm{mU} \mathrm{min}{ }^{-1} \mathrm{~m}^{-2}\right.$ )-isoglycaemic clamp tests. Beta cell function was evaluated by calculating insulinogenic index (IGI) from C-peptide AUC:glucose AUC ratios from the first hour of OGTT (IGI[60 min]) and from the total OGTT (IGI[120 min]).

Results During the OGTT, the offspring of individuals with type 2 diabetes showed $4-14 \%$ higher plasma glucose from 30 to $120 \mathrm{~min}(p<0.05)$ and $20-29 \%$ higher serum insulin from 90 to $120 \mathrm{~min}$, but decreased IGI(60 $\mathrm{min})$ and IGI (120 min) $(p<0.05) . M / I$ was $11 \%$ lower in the offspring of affected individuals than in controls $(p<0.01)$. To study the offspring of patients with type 2 diabetes with insulin sensitivity similar to that of the control group, the offspring of affected patients were divided into $M / I$ quartiles. Those in the third $M / I$ quartile showed $M / I$ values and major anthropometric characteristics similar to those of the controls, but insulin AUC and C-peptide AUC values were lower in the first hour and the total OGTT $(p<0.05)$. The third $M / I$ quartile had lower IGI values at $60 \mathrm{~min}$ and $120 \mathrm{~min}: 11 \%$ and $14 \%$ lower, respectively $(p<0.02)$.

Conclusions/interpretation The first-degree offspring of type 2 diabetic patients show insulin resistance and beta cell dysfunction in response to oral glucose challenge. Beta cell impairment exists in insulin-sensitive offspring of patients with type 2 diabetes, suggesting beta cell dysfunction to be a major defect determining diabetes development in diabetic offspring.

Keywords Beta cell function - Diabetes offspring . Insulin resistance · Type 2 diabetes mellitus 
Abbreviations

$\triangle \mathrm{AUC}$

Controls 2

C-peptide AUC

C-peptide AUC

(60 min)

Insulin AUC

Insulin AUC

(60 min)

Glucose AUC

IGI

IGI(60 min)

IGI(120 min)

M/I

Offspring

RISC
Dynamic AUC (i.e. total AUC-basal

concentration $\times 120 \mathrm{~min}$ )

Control group 2, pair-matched with third $M / I$ quartile of offspring

AUC of C-peptide during the $2 \mathrm{~h}$ OGTT

AUC of C-peptide in the first hour of

OGTT

AUC of insulin during the $2 \mathrm{~h}$ OGTT

AUC of insulin in the first hour of

OGTT

AUC of glucose during the $2 \mathrm{~h}$ OGTT

Insulinogenic index; ratio of C-peptide

AUC and glucose AUC

Ratio of values from first hour of

OGTT

Ratio of values from the $2 \mathrm{~h}$ OGTT

$M$ value divided by clamp insulin $\times 100$

First-degree offspring of individuals with

type 2 diabetes mellitus

Relationship between Insulin Sensitivity

and Cardiovascular risk

\section{Introduction}

Both insulin resistance and insulin deficiency precede and contribute to the development of type 2 diabetes mellitus [1-3]. The metabolic syndrome is characterised by insulin resistance [4] and hyperinsulinaemia [5] and is associated with visceral obesity, dyslipidaemia, arterial hypertension and non-alcoholic fatty liver [6]. Insulin resistance not only occurs in virtually all patients with type 2 diabetes [7], but is also present in healthy, firstdegree offspring of type 2 diabetic patients (offspring). Furthermore, offspring of type 2 diabetic patients bear a lifetime risk for developing type 2 diabetes of $\sim 40 \%$ [8], and their degree of insulin resistance is able to predict type 2 diabetes onset [2].

During the past three decades, the relative contribution of insulin resistance and beta cell dysfunction to type 2 diabetes development has been the subject of many debates, and a feedback loop between peripheral insulin-sensitive tissues (skeletal muscle, adipose tissue and liver) and the beta cell has been postulated $[9,10]$. This association between insulin sensitivity and beta cell secretion in nondiabetic individuals was well suited to relate the markedly increased, though qualitatively and quantitatively altered, insulin release in insulin resistance with that in insulinsensitive humans [9]. However, it still remains unclear which of the two defects is more deleterious in the offspring of type 2 diabetic patients. As both these defects appear in

combination [10, 11], insulin resistance and beta cell dysfunction are inseparable phenomena in the offspring of type 2 diabetic patients. Under these circumstances, it would be anticipated therefore that the offspring of type 2 diabetic patients without insulin resistance would not have any beta cell defect.

We aimed to characterise the beta cell function of the offspring of type 2 diabetic patients and compare it with that in individuals without a family history of diabetes (controls), and in particular to compare the controls with a subgroup of the offspring group with similar insulin sensitivity to test whether or not the offspring of type 2 diabetic patients without insulin resistance would display defects of beta cell function.

\section{Methods}

The study population is part of the prospective Relationship between Insulin Sensitivity and Cardiovascular risk (RISC) study cohort [12]. From 2002 to 2004, individuals were recruited in 19 centres in 14 European countries [12]. They were screened initially to confirm excellent health and the absence of any regular drug intake that may affect insulin sensitivity, blood pressure, circulating lipids or glucose. All participants included in the study were between 30 and 60 years old.

Exclusion criteria were: elevated systolic and diastolic blood pressure (systolic/diastolic: $>140 />90 \mathrm{mmHg}$ ) in one or more of three measurements; pronounced hyperlipidaemia (fasting circulating cholesterol $[>7.77 \mathrm{mmol} / \mathrm{l}]$ and/or triacylglycerol $[>4.52 \mathrm{mmol} / 1]$ ); diabetes mellitus (fasting and $2 \mathrm{~h}$ glucose $\geq 6.99 \mathrm{mmol} / 1$ and/or $\geq 11.1 \mathrm{mmol} / \mathrm{l}$, respectively); the presence of other chronic diseases, such as overt cardiovascular disease (clinical cardiovascular disease was excluded on the basis of medical history and resting electrocardiogram); carotid stenosis $>40 \%$; and treatment for hypertension, diabetes or dyslipidaemia. Local ethics committee approval was obtained by each recruitment centre, and all participants gave informed written consent to participate in the study.

In this study, we selected from the entire database $(n=1324)$ all participants with first-degree relatives with type 2 diabetes $(n=187)$ and excluded participants with a family history of cardio- or cerebrovascular disease. We selected a control group $(n=519)$ from the RISC participants without type 2 diabetes or vascular disease in their family history, who were comparable for major anthropometric characteristics with the offspring group (Table 1). The offspring group was further divided into quartiles according to the main readout of insulin sensitivity, namely $M$ value divided by clamp insulin concentration $(M / I$; Table 1$)$. 
Table 1 Anthropometric characteristics, routine laboratory measurements and insulin sensitivity from the isoglycaemic-hyperinsulinaemic clamp test $(M / I$ value) in humans without type 2 diabetes mellitus in the family anamnesis (controls), offspring of type 2 diabetic patients (offspring), offspring according to $M / I$ value quartiles and a subgroup of controls who were pair-matched with the third $M / I$ quartile of the offspring group (controls 2)

\begin{tabular}{|c|c|c|c|c|c|c|c|c|}
\hline \multirow[t]{2}{*}{ Characteristic } & \multirow[t]{2}{*}{ Con } & \multirow[t]{2}{*}{ Con 2} & \multirow[t]{2}{*}{ Offspring } & \multicolumn{4}{|c|}{ Offspring $M / I$ quartiles } & \multirow{2}{*}{$\begin{array}{l}p \text { ANOVA (Bonferroni } \\
\text { post hoc) }\end{array}$} \\
\hline & & & & $1 \mathrm{st}$ & 2 nd & $3 \mathrm{rd}$ & 4 th & \\
\hline$n(\%)$ & 519 & 46 & 187 & $46(25)$ & $45(25)$ & $46(25)$ & $50(25)$ & \\
\hline Age (years) & $43.4 \pm 8.2$ & $43.3 \pm 1.4$ & $43.8 \pm 8.1$ & $45.6 \pm 7.9$ & $42.5 \pm 7.5$ & $43.1 \pm 9.4$ & $44.3 \pm 7.4$ & NS \\
\hline Women/men & $283 / 236$ & $25 / 21$ & $107 / 80$ & $23 / 23$ & $25 / 20$ & $25 / 21$ & $34 / 16$ & NS $\left(\chi^{2}\right.$ tests $)$ \\
\hline $\begin{array}{l}M / I\left(\mathrm{mg} \mathrm{kg}^{-1}\right. \\
\quad \min ^{-1}\left[\mu \mathrm{U} / \mathrm{ml}^{-1}\right)^{\mathrm{a}}\end{array}$ & $12.2 \pm 6.3$ & $11.8 \pm 0.5$ & $10.8 \pm 5.2^{* *}$ & $5.1 \pm 1.4$ & $8.6 \pm 0.9$ & $11.9 \pm 1.1$ & $17.7 \pm 4.1$ & $\begin{array}{l}<0.0001 \text { (1st, 2nd, 4th } \\
\text { vs con; } 1 \text { st vs } 2 \text { nd }-4 \text { th, } \\
\text { 2nd vs 3rd; 4th vs } 3 \text { rd) }\end{array}$ \\
\hline $\begin{array}{l}M / I \text { range }\left(\mathrm{mg} \mathrm{kg}^{-1}\right. \\
\min ^{-1}\left[\mu \mathrm{U} / \mathrm{ml}^{-1}\right)^{\mathrm{a}}\end{array}$ & $1.3-47.4$ & $6.1-19.6$ & $1.4-30.5$ & $1.4-7.2$ & $7.2-10.0$ & $10.0-13.7$ & $13.7-30.5$ & \\
\hline BMI $\left(\mathrm{kg} / \mathrm{m}^{2}\right)$ & $26.4 \pm 3.7$ & $26.0 \pm 0.5$ & $26.8 \pm 4.5$ & $30.6 \pm 4.4$ & $27.3 \pm 4.1$ & $25.6 \pm 3.6$ & $23.9 \pm 3.1$ & $\begin{array}{l}<0.0001 \text { (1st vs } 2 \text { nd }-4 \text { th } \\
\text { and con; } 4 \text { th vs } 1 \text { st }-3 \text { rd } \\
\text { and con) }\end{array}$ \\
\hline $\begin{array}{l}\text { Fat-free body mass } \\
(\%)\end{array}$ & $71.0 \pm 0.4$ & $71.4 \pm 1.3$ & $70.3 \pm 0.6$ & $65.6 \pm 1.3$ & $69.1 \pm 1.3$ & $72.8 \pm 1.2$ & $73.4 \pm 1.1$ & $\begin{array}{l}<0.0001 \text { (1st vs } 3 \text { rd, 4th } \\
\text { and con; 4th vs } 1 \text { st } \\
\text { and con) }\end{array}$ \\
\hline $\begin{array}{l}\text { Waist circumference } \\
(\mathrm{cm})\end{array}$ & $89 \pm 12$ & $87 \pm 2$ & $90 \pm 14$ & $99 \pm 12$ & $92 \pm 14$ & $87 \pm 13$ & $82 \pm 12$ & $\begin{array}{l}<0.0001 \text { (1st vs } 2 \text { nd }-4 \text { th } \\
\text { and con; } 2 \text { nd vs } 3 \text { rd; } \\
\text { 4th vs } 1 \text { st, } 2 \text { nd and con }\end{array}$ \\
\hline Systolic BP (mmHg) & $118 \pm 12$ & $117 \pm 2$ & $117 \pm 12$ & $121 \pm 12$ & $117 \pm 11$ & $117 \pm 12$ & $115 \pm 14$ & NS \\
\hline Diastolic BP (mmHg) & $75 \pm 8$ & $74 \pm 1$ & $74 \pm 8$ & $76 \pm 8$ & $74 \pm 8$ & $73 \pm 8$ & $74 \pm 9$ & NS \\
\hline Plasma cholesterol (mmol/1) & $4.82 \pm 0.04$ & $4.59 \pm 0.13$ & $4.81 \pm 0.07$ & $4.91 \pm 0.14$ & $4.88 \pm 0.16$ & $4.78 \pm 0.13$ & $4.69 \pm 0.11$ & NS \\
\hline $\begin{array}{l}\text { Plasma LDL-cholesterol } \\
(\mathrm{mmol} / \mathrm{l})\end{array}$ & $2.89 \pm 0.04$ & $2.80 \pm 0.11$ & $2.93 \pm 0.06$ & $3.04 \pm 0.13$ & $3.05 \pm 0.15$ & $2.90 \pm 0.13$ & $2.72 \pm 0.10$ & NS \\
\hline $\begin{array}{l}\text { Plasma HDL-cholesterol } \\
(\mathrm{mmol} / \mathrm{l})\end{array}$ & $1.40 \pm 0.02$ & $1.37 \pm 0.05$ & $1.37 \pm 0.03$ & $1.17 \pm 0.05$ & $1.35 \pm 0.05$ & $1.40 \pm 0.06$ & $1.56 \pm 0.06$ & $\begin{array}{l}<0.002 \text { (1st vs } 3 \mathrm{rd}, 4 \text { th } \\
\text { and con; 4th vs } 1 \mathrm{st} \\
\text { and con) }\end{array}$ \\
\hline \multirow[t]{2}{*}{$\begin{array}{l}\text { Plasma triacylglycerol } \\
(\mathrm{mmol} / \mathrm{l})\end{array}$} & \multirow[t]{2}{*}{$1.14 \pm 0.03$} & \multirow[t]{2}{*}{$1.37 \pm 0.05$} & \multirow[t]{2}{*}{$1.14 \pm 0.08$} & \multirow[t]{2}{*}{$1.65 \pm 0.27$} & \multirow[t]{2}{*}{$1.05 \pm 0.08$} & \multirow[t]{2}{*}{$1.40 \pm 0.06$} & \multirow[t]{2}{*}{$0.86 \pm 0.05$} & $\begin{array}{l}<0.0004 \text { (1st vs } 2 \text { nd }-4 \text { th } \\
\text { and con) }\end{array}$ \\
\hline & & & & & & & & $<0.03$ (4th vs con) \\
\hline $\begin{array}{l}\text { Serum creatinine } \\
(\mu \mathrm{mol} / \mathrm{l})\end{array}$ & $80.5 \pm 0.6$ & $80.1 \pm 1.7$ & $78.9 \pm 1.1$ & $79.0 \pm 2.0$ & $78.4 \pm 2.4$ & $79.0 \pm 2.1$ & $79.1 \pm 2.2$ & NS \\
\hline ASAT (U/1) & $35 \pm 14$ & $36 \pm 3$ & $34 \pm 12$ & $35 \pm 12$ & $32 \pm 9$ & $34 \pm 14$ & $36 \pm 13$ & NS \\
\hline ALAT (U/1) & $39 \pm 21$ & $36 \pm 3$ & $39 \pm 18$ & $43 \pm 18$ & $40 \pm 21$ & $38 \pm 19$ & $35 \pm 14$ & NS \\
\hline
\end{tabular}

All data are given as mean $\pm \mathrm{SD}$, absolute numbers of cases or percentage of cases

Data tested with ANOVA with post hoc testing (offspring $M / I$ quartiles vs con) and two-tailed Student's $t$ test (offspring vs con and offspring third $M / I$-quartile vs con 2)

${ }^{\text {a }}$ To convert values to $\mathrm{mmol} \mathrm{kg}{ }^{-1} \min ^{-1}$ (pmol/1) $)^{-1}$, multiply by 0.00008

$* * p<0.01$ offspring vs con

ALAT, alanine aminotransaminase; ASAT, aspartate aminotransaminase; Con, controls; Con 2, controls 2

Study day 1

After confirmation that the participants had fasted overnight for at least $10 \mathrm{~h}$, medical history, medical family history and medication intake were recorded on a questionnaire. Sitting blood pressure was measured three times (Omron $705 \mathrm{cp}$, Omron Healthcare Europe, Hoofddorp, the Netherlands), and the mean of these three measurements was used for the statistical analyses. The study participants underwent a thorough clinical examination to confirm excellent health following a routine laboratory check. Body weight and composition were measured by the Tanita Bioimpedance Balance (TBF-300 body composition analyser, Tanita International Division, Yiewsley, UK) [13] and waist circumference was measured as the narrowest circumference between the lower rib margin and anterior superior iliac crest $[12,13]$.

Thereafter, an OGTT was started $[14,15]$. The participants drank $75 \mathrm{~g}$ of glucose within $5 \mathrm{~min}$. Blood samples 
for the determination of plasma glucose as well as serum insulin and C-peptide were obtained at 0,30, 60, 90 and $120 \mathrm{~min}$. The participants remained in sitting or supine position throughout the entire OGTT.

\section{Study day 2}

After a further overnight fast for at least $12 \mathrm{~h}$, two catheters (Vasofix, Braun, Melsungen, Germany) were inserted into one antecubital vein in the left and right arms for blood sampling and infusions, respectively. The isoglycaemic clamp glucose target was determined from the mean value of three fasting plasma glucose measurements. However, in the case of a value lower than $4.44 \mathrm{mmol} / \mathrm{l}$, the glucose clamp target was set to $4.44 \mathrm{mmol} / \mathrm{l}$, and in the case of a value higher than $5.55 \mathrm{mmol} / \mathrm{l}$, the clamp goal was then $5.55 \mathrm{mmol} / \mathrm{l}$. Hyperinsulinaemic-isoglycaemic clamps were performed for $120 \mathrm{~min}$, with primed (0-4 min: fourfold rate; 5-7 min: twofold rate) continuous regular insulin infusion (40 mU insulin $\min ^{-1} \mathrm{~m}^{-2}$ body surface area) $[7,16,17]$.

\section{Plasma metabolites and hormones}

Plasma glucose was measured by the glucose oxidase technique (Glucose Analyzer; Beckman Coulter, Fullerton, CA, USA). Serum concentrations of insulin and levels of triacylglycerol and serum total and HDL-cholesterol were assayed by standard methods in a central laboratory [13]. Plasma LDL-cholesterol was calculated by the Friedewald formula [13].

\section{Calculations}

Whole-body insulin sensitivity was expressed as the ratio between the $M$ value (mg glucose $\min ^{-1} \mathrm{~kg}^{-1}$ total body weight; to convert values to $\mathrm{mmol} \mathrm{kg}^{-1} \mathrm{~min}^{-1}$, multiply by 0.0555 ) during the final 40 min interval of the $2 \mathrm{~h}$ clamp test [7] and the mean plasma insulin concentration during the same interval, multiplied by $100\left(M / I ;\left[\mathrm{mg} \mathrm{kg}^{-1} \mathrm{~min}^{-1}\right]\right.$ $\left[\mu \mathrm{U} / \mathrm{ml}^{-1}\right.$; to convert values to $\mathrm{mmol} \mathrm{kg}{ }^{-1} \mathrm{~min}^{-1}(\mathrm{pmol} / \mathrm{l})^{-1}$, multiply by 0.00008 ). Total AUCs during the $2 \mathrm{~h}$ OGTT of glucose (glucose AUC), insulin (insulin AUC) and C-peptide (C-peptide AUC) were calculated with the trapezoidal rule. Dynamic AUC $(\triangle \mathrm{AUC})$ was calculated as total AUC-basal concentration $\times 120$ min $[14,15]$. Beta cell function was evaluated as the C-peptide response to the glycaemic stimulus. We adopted the same concept of the insulinogenic index, an OGTT-based measure which has been widely used [18]. The index we calculated, insulinogenic index (IGI), is the ratio between C-peptide AUC and glucose AUC at two different time intervals: (1) the first hour of OGTT (IGI [60 min]) [18]; and (2) for the entire OGTT period (IGI
[120 min]). At variance with the classic insulinogenic index, we increased the precision of the measurement by using AUCs instead of a single data point [18]; in addition, we used C-peptide instead of insulin, being interested in the actual response at beta cell level. Hepatic insulin extraction was estimated as [1-(insulin AUC/C-peptide AUC)] as previously described [15].

\section{Statistics}

Before further analysis, the variables were tested for a normal distribution by applying the Kolmogorov-Smirnov test for the entire study population and each subgroup separately. This test showed that all of the variables except for plasma triacylglycerol were normally distributed. Therefore, plasma triacylglycerol values were logarithmically transformed to achieve normal distribution and statistical tests were applied to the transformed variable [16]. Comparisons between two and more than two groups were performed by the two-sided Student's $t$ test for unpaired data, paired $t$ test for paired data and ANOVA following Bonferroni and least significant difference (LSD) post hoc tests, respectively (SPSS 13.0, SPSS, Chicago, IL, USA). Data are given as means $\pm \mathrm{SEM} / \mathrm{SD}$, as indicated. Pearson's product moment correlation was used to estimate linear relationships between variables. Differences were considered statistically significant when $p<0.05$.

Multiple linear regression analysis, based on the data from all participants, was applied. In the first model, the OGTT-based indicator of beta cell function IGI(60 min) was used as a dependent variable. Variables correlating with IGI(60 min) on a level of $p<0.05$ and sex and family history of diabetes were considered for the first model to find possible predictors for IGI(60 min). Outliers ( $>$ three standard deviations) were excluded casewise $(n=6)$. Predictors of IGI(60 min) at a significance level of $p<0.1$ remained in the model, as described in detail elsewhere $[16,19]$. The final model was verified by backward stepwise linear multiple regression analysis.

\section{Results}

Anthropometric characteristics and routine laboratory measurements

The two groups were similar in sex distribution, age and anthropometric characteristics, such as BMI and waist circumference. Systolic and diastolic blood pressure measurements as well as circulating concentrations of creatinine, lipids and liver transaminases in the routine laboratory analyses were comparable (Table 1). 
When the offspring group was divided into $M / I$ quartiles (Table 2), the participants did not differ among the quartiles and in comparison with controls in terms of age, sex distribution, blood pressure, total and LDL-cholesterol, serum creatinine and liver transaminases. However, BMI, waist circumference and plasma triacylglycerol were lowest in the fourth $M / I$ quartile of offspring (BMI: vs controls and first to third quartiles; waist: vs controls and first and second quartiles; triacylglycerol: vs controls and first quartile; Table 1) and highest in the first $M / I$ quartile (vs controls and second to fourth quartiles). Plasma HDLcholesterol and percentage of fat-free body mass were lowest in the first $M / I$ quartile (vs controls and third and fourth quartiles; Table 1) and highest in the fourth $M / I$ quartile (vs controls and first quartile).

As, in addition to the $M / I$ value, all major anthropometric and routine laboratory characteristics of offspring in the third $M / I$ quartile were comparable with those of the controls (Table 1), the third $M / I$ quartile of the offspring group was chosen to investigate beta cell function without insulin insensitivity [14].

From the control group, a subgroup of individuals pairmatched with the participants of the third $M / I$ quartile of the offspring group for age, sex and BMI was selected (controls 2) in order to control the results for insulin resistance (Table 1).

\section{The hyperinsulinaemic clamp test}

The concentrations of metabolites and hormones during the isoglycaemic-hyperinsulinaemic clamp test are presented in Table 3. Plasma glucose was similar at fasting and during the last clamp interval. Fasting serum insulin was comparable in the two groups and was similarly increased during the clamp. The serum concentrations of C-peptide were not different at fasting and during the clamp. At fasting, plasma NEFA level was higher by $\sim 9 \%$ in the offspring group when compared with controls $(p<0.02)$. Plasma NEFA levels were comparable in the two groups during the hyperinsulinaemic clamp test. The $M / I$ value in the offspring group was $\sim 11 \%$ lower than in control group $(p<0.01$; Table 1).

\section{Oral glucose tolerance test}

Fasting plasma glucose levels were comparable between the groups, whereas the offspring group, which was more insulin resistant than the controls (Table 1) had higher plasma glucose by $4-14 \%$ between $30 \mathrm{~min}$ and the end of the OGTT $(p<0.05$ vs controls; Fig. 1a). Accordingly, glucose AUC and glucose $\triangle$ AUC during the $2 \mathrm{~h}$ of OGTT were $8 \%$ and $27 \%$ higher, respectively (both $p<0.0001$; Table 2). The offspring had $20-29 \%$ higher serum insulin concentrations between 90 and 120 min of OGTT ( $p<0.05$ vs controls; Fig. 1b). Serum C-peptide concentrations during the OGTT were not different in the offspring in comparison with the controls (Fig. 1c). The total AUC and $\triangle \mathrm{AUC}$ of insulin and C-peptide in the first hour and the entire course of the OGTT were not different between the two groups (Table 2). In the offspring group, the insulinogenic index of the total OGTT and in the first hour of OGTT were $6 \%$ and $8 \%$ lower, respectively (each $p<0.05$ vs controls). Hepatic insulin extraction was $3.9 \%$ lower in the offspring group than in the controls $(p<0.05$; Table 2$)$.

\section{OGTT in offspring with third $M / I$ quartile}

During the OGTT, the third M/I quartile of the offspring group showed plasma glucose concentrations similar to those of the controls and the controls 2 subgroup (Fig. 1d). During the first OGTT hour, the third M/I quartile of the offspring group had 18-26\% lower serum insulin concentrations than the controls and $22 \%$ lower serum insulin concentrations than controls 2 at $30 \mathrm{~min}$. Serum C-peptide concentrations were $12-17 \%$ lower in the first hour of OGTT than in the controls and controls $2(p<0.05$ in both instances, Fig. 1e, f). Accordingly, the third $M / I$ quartile of the offspring group had total insulin AUC and C-peptide AUC values that were lower by $20 \%$ and $11 \%$, respectively, than those of the controls $(p<0.05$; Table 2$)$. Total Cpeptide AUC was $15 \%$ lower than that of the pair-matched controls 2 subgroup $(p<0.05$; Table 2$)$.

In the third $M / I$ quartile of the offspring group, insulin AUC in the first hour of OGTT AUC(60 min) and C-peptide AUC (60 min) were lower by $24 \%$ and $13 \%$, respectively, than in the controls ( $p<0.05$ in both instances; Table 2$)$ and by $23 \%$ and $18 \%$, respectively, than in the controls 2 subgroup ( $p<0.05$ in both instances; Table 2$)$. Dynamic and total glucose AUC, insulin $\triangle \mathrm{AUC}$ and $\mathrm{C}$-peptide $\triangle \mathrm{AUC}$ were not different between the third $M / I$ quartile of the offspring group, the controls and the controls 2 subgroup (Table 2). In the third $M / I$ quartile, the insulinogenic index in the first hour of OGTT and from the total OGTT was lower by $14 \%$ and $11 \%$, respectively, in comparison with the controls $(p<0.02$; Table 2$)$ and by $16 \%$ and $20 \%$, respectively, when compared with the controls 2 subgroup $(p<$ 0.01; Table 2). Hepatic insulin extraction was not different between the third $M / I$ quartile of the offspring group, the controls and the controls 2 subgroup.

Correlation analyses in all participants

The correlations of the $M / I$ value as well as IGI(60 min), IGI(120 min) and of insulin AUC(60 min) during OGTT with anthropometrical and serochemical characteristics are shown in Table 4. 


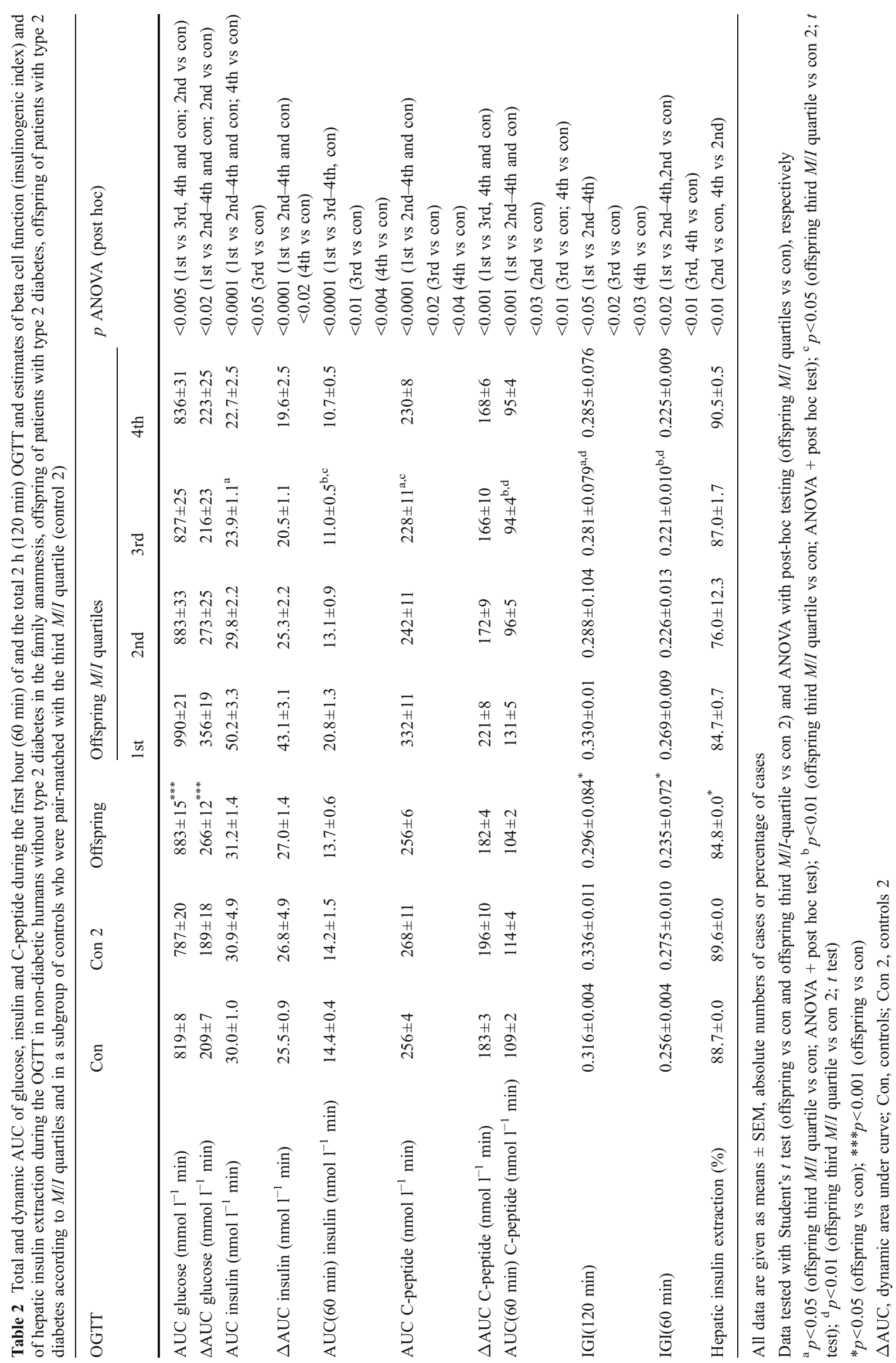


Table 3 Concentrations of plasma glucose and NEFA and serum insulin and C-peptide during the isoglycaemic-hyperinsulinaemic clamp test in the offspring and control groups

\begin{tabular}{|c|c|c|c|}
\hline Isoglycaemic-hyperinsulinaemic clamp test & Con & Offspring & $p$ value ( $t$ test) \\
\hline Plasma glucose 0 min $(\mathrm{mmol} / \mathrm{l})$ & $5.20 \pm 0.03$ & $5.23 \pm 0.06$ & NS \\
\hline Plasma glucose $80 \mathrm{~min}(\mathrm{mmol} / \mathrm{l})$ & $4.96 \pm 0.04$ & $4.99 \pm 0.08$ & NS \\
\hline Plasma glucose $120 \mathrm{~min}(\mathrm{mmol} / \mathrm{l})$ & $5.03 \pm 0.05$ & $5.01 \pm 0.05$ & NS \\
\hline Serum insulin $0 \mathrm{~min}(\mathrm{pmol} / \mathrm{l})$ & $53.7 \pm 6.4$ & $40.9 \pm 5.8$ & NS \\
\hline Serum insulin $80 \mathrm{~min}(\mathrm{pmol} / \mathrm{l})$ & $427.3 \pm 5.9$ & $420.3 \pm 9.2$ & NS \\
\hline Serum insulin $120 \mathrm{~min}(\mathrm{pmol} / \mathrm{l})$ & $416.4 \pm 5.4$ & $421.3 \pm 9.4$ & NS \\
\hline Serum C-peptide $0 \min (\mathrm{pmol} / \mathrm{l})$ & $563.4 \pm 11.8$ & $565.8 \pm 17.6$ & NS \\
\hline Serum C-peptide $80 \mathrm{~min}(\mathrm{pmol} / \mathrm{l})$ & $591.0 \pm 15.6$ & $563.2 \pm 24.5$ & NS \\
\hline Serum C-peptide $120 \mathrm{~min}(\mathrm{pmol} / \mathrm{l})$ & $553.0 \pm 15.6$ & $514.4 \pm 24.4$ & NS \\
\hline Plasma NEFA 0 min $(\mu \mathrm{mol} / \mathrm{l})$ & $527 \pm 10$ & $577 \pm 18$ & $<0.02$ \\
\hline Plasma NEFA $80 \min (\mu \mathrm{mol} / \mathrm{l})$ & $65 \pm 6$ & $71 \pm 8$ & NS \\
\hline Plasma NEFA $120 \min (\mu \mathrm{mol} / 1)$ & $56 \pm 6$ & $52 \pm 6$ & NS \\
\hline
\end{tabular}

All data are given means \pm SEM

Data tested with two-tailed Student's $t$ test

Con, controls

Multiple regression analyses in all participants

Predictors of insulinogenic index $(60 \mathrm{~min})$ in all participants Age, waist circumference, BMI, M/I, fasting plasma HDL-cholesterol, triacylglycerol and the factors 'family history of diabetes' and sex were included in the first model. The stepwise backward regression performed with the remaining variables revealed that a positive family history of diabetes $(\beta=-0.143, p<0.0001), M / I$ value $(\beta=-0.213, p<0.0001)$ and (female) sex $(\beta=0.15, p<$ $0.0001)$ were the strongest predictors of insulinogenic index (60 min). BMI $(\beta=0.094, p<0.03)$, age $(\beta=-0.123$, a

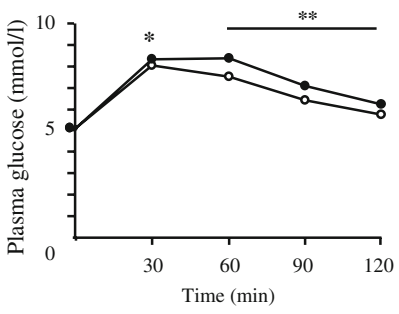

d

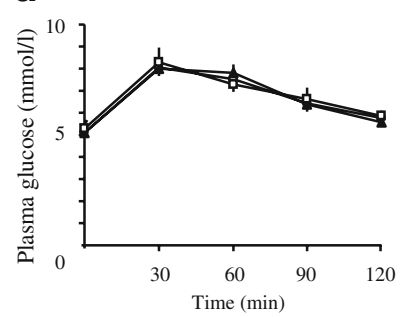

b

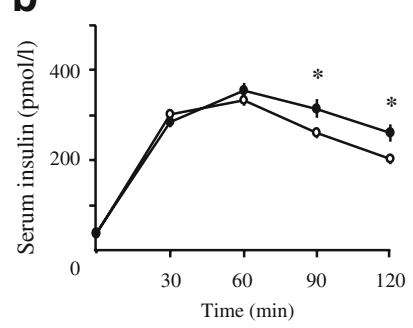

.

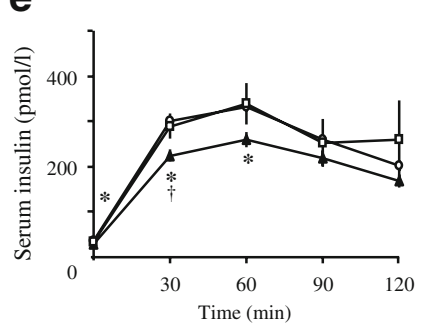

C

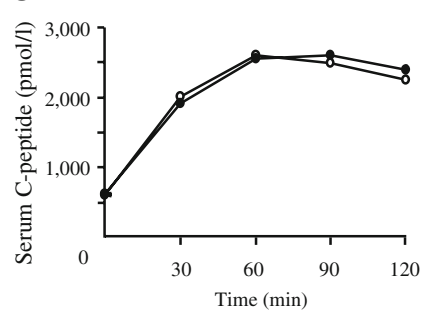

f

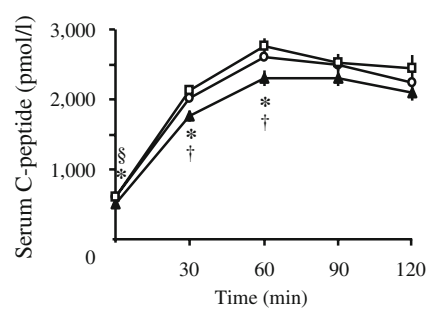

Fig. 1 Circulating concentrations of (a, d) plasma glucose, (b, e) serum insulin and $(\mathbf{c}, \mathbf{f})$ serum C-peptide during the OGTT in: the offspring of patients with type 2 diabetes (black circles) and the control group (white circles) $(\mathbf{a}-\mathbf{c})$; the third $M / I$ quartile of the offspring group (black triangles), control group (white circles) a subgroup of controls pair-matched with the third M/I quartile (control
2, white squares) (d-f). All data are given as means \pm SEM (Student's $t$ test in control groups vs offspring group and in third $M / I$ quartile vs control 2, ANOVA and post hoc testing in $M / I$ quartiles vs control group, respectively). ${ }^{*} p<0.05$ vs controls; ${ }^{* *} p<0.01$ vs controls; ${ }^{\dagger} p<0.05$ vs control 2 
Table 4 Pearson's product moment correlations of anthropometric characteristics, routine laboratory measurements including circulating lipids, renal function, fasting and $2 \mathrm{~h}$ clamp plasma glucose and serum insulin, with the AUC(60 min) of insulin, the IGI(60 min), IGI (120 min) and with $M / I$ from the hyperinsulinaemic clamp test in all participants

\begin{tabular}{|c|c|c|c|c|}
\hline \multirow[t]{2}{*}{ Characteristic } & \multirow[t]{2}{*}{ Clamp $M / I$} & \multicolumn{3}{|l|}{ OGTT } \\
\hline & & IGI $0-120 \mathrm{~min}$ & IGI $0-60 \mathrm{~min}$ & $\begin{array}{l}\text { AUC insulin } \\
0-60 \mathrm{~min}\end{array}$ \\
\hline Age (years) & -0.03 & -0.07 & $-0.13 \dagger$ & -0.03 \\
\hline BMI $\left(\mathrm{kg} / \mathrm{m}^{2}\right)$ & $-0.47 \dagger$ & $0.15 \dagger$ & $0.17 \dagger$ & $0.35 \dagger$ \\
\hline Waist circumference $(\mathrm{cm})$ & $-0.40 \dagger$ & 0.06 & $0.10^{*}$ & $0.27 \dagger$ \\
\hline Systolic BP (mmHg) & $-0.10^{*}$ & -0.03 & -0.03 & $0.10 *$ \\
\hline Diastolic BP (mmHg) & $-0.15 * * *$ & -0.02 & 0.00 & $0.13 * * *$ \\
\hline Creatinine $(\mu \mathrm{mol} / \mathrm{l})$ & -0.02 & -0.01 & -0.00 & 0.05 \\
\hline Plasma cholesterol (mmol/l) & -0.07 & 0.01 & 0.00 & 0.00 \\
\hline Plasma HDL-cholesterol (mmol/l) & $0.32 \dagger$ & $-0.32 \dagger$ & $-0.13 * * *$ & $-0.14 * * *$ \\
\hline Plasma LDL-cholesterol (mmol/l) & $-0.11^{*}$ & $0.08^{*}$ & 0.01 & 0.01 \\
\hline Plasma triacylglycerol $(\mathrm{mmol} / \mathrm{l})$ & $-0.25 \dagger$ & $0.26 \dagger$ & $0.13 * * *$ & $0.13^{* * *}$ \\
\hline Clamp plasma glucose $0 \mathrm{~min}(\mathrm{mmol} / \mathrm{l})$ & $-0.12 *$ & -0.02 & -0.04 & $0.10^{* * *}$ \\
\hline Clamp plasma glucose $120 \mathrm{~min}(\mathrm{mmol} / \mathrm{l})$ & -0.02 & -0.02 & -0.02 & 0.21 \\
\hline Clamp serum insulin $0 \mathrm{~min}(\mathrm{pmol} / \mathrm{l})$ & $-0.08^{*}$ & 0.05 & 0.05 & $0.12 *$ \\
\hline Clamp serum insulin $120 \mathrm{~min}(\mathrm{pmol} / \mathrm{l})$ & $-0.45 \dagger$ & $0.12 *$ & $0.10^{*}$ & $0.25 \dagger$ \\
\hline Clamp serum C-peptide 0 min $(\mathrm{pmol} / \mathrm{l})$ & $-0.45 \dagger$ & $0.38 \dagger$ & $0.39 \dagger$ & $0.51 \dagger$ \\
\hline clamp serum C-peptide $120 \mathrm{~min}(\mathrm{pmol} / \mathrm{l})$ & -0.01 & $0.31 \dagger$ & $0.29 \dagger$ & $0.23 \dagger$ \\
\hline$M / I\left(\mathrm{mg} \mathrm{kg}^{-1} \min ^{-1}[\mu \mathrm{U} / \mathrm{ml}]^{-1}\right)^{\mathrm{a}}$ & & $-0.26 \dagger$ & $-0.25 \dagger$ & $-0.44 \dagger$ \\
\hline AUC glucose (mmol l-1 $\mathrm{min})$ & $-0.35 \dagger$ & $-0.25 \dagger$ & $-0.31 \dagger$ & $0.22 \dagger$ \\
\hline AUC insulin ( $\left.\mathrm{nmol} 1^{-1} \min \right)$ & $-0.47 \dagger$ & $0.51 \dagger$ & 0.45 & $0.89 \dagger$ \\
\hline AUC C-peptide (nmol $1^{-1} \min$ ) & $-0.47 \dagger$ & $0.72 \dagger$ & 0.63 & $0.74 \dagger$ \\
\hline AUC insulin 0-60 min ( $\left.\mathrm{nmol} \mathrm{l}^{-1} \mathrm{~min}\right)$ & $-0.43 \dagger$ & $0.59 \dagger$ & $0.61 \dagger$ & \\
\hline AUC C-peptide $0-60 \min \left(\mathrm{nmol} 1^{-1} \min \right)$ & $-0.42 \dagger$ & $0.81 \dagger$ & $0.79 \dagger$ & $0.79 \dagger$ \\
\hline
\end{tabular}

${ }^{\text {a }}$ To convert values to $\mathrm{mmol} \mathrm{kg} \mathrm{kg}^{-1} \mathrm{~min}^{-1}(\mathrm{pmol} / \mathrm{l})^{-1}$, multiply by 0.00008

${ }^{*} p<0.05 ; * * * p<0.001 ; \dagger p<0.00001$

$p<0.001)$ and fasting plasma HDL-cholesterol $(\beta=-0.102$, $p<0.03)$ were predictors of insulinogenic index $(60 \mathrm{~min})$ and remained in the model $(R=0.35)$.

\section{Discussion}

The present study investigated beta cell function in relation to insulin resistance in a large population $(n=706)$ of individuals, from 14 different European countries, with and without a family history of type 2 diabetes, and not taking drugs affecting glucose metabolism. This study found that: (1) the offspring of type 2 diabetes patients are less insulin sensitive and display higher plasma glucose concentrations after oral glucose challenge than controls and are hyperinsulinaemic in the second phase of OGTT; (2) the offspring of type 2 diabetes patients are characterised by decreased beta cell function (insulinogenic index) during OGTT; (3) the offspring without insulin resistance (third
$M / I$ quartile) have defects in early-phase and total OGTT insulin secretion (AUC insulin) and beta cell function (insulinogenic index). Importantly, neither the offspring group nor the insulin-sensitive third $M / I$ quartile differed from the controls in any anthropometric characteristic or routine laboratory measurement. Therefore, this study shows for the first time in a large number of healthy humans that the offspring of type 2 diabetes patients have beta cell defects, even in the absence of insulin resistance, suggesting that beta cell dysfunction is not necessarily bound to insulin insensitivity.

Insulin sensitivity

In this study, healthy offspring of type 2 diabetes patients were less insulin sensitive, as they had a lower $M / I$ measured by the gold-standard isoglycaemic-hyperinsulinaemic clamp test, in comparison with age-, BMI- and sex-matched controls, which is in line with numerous studies by others 
and ourselves [2, 8, 14]. This was also reflected in higher plasma glucose concentrations after oral glucose challenge and in hyperinsulinaemia in the second phase of OGTT. First-degree relatives of type 2 diabetes patients have a lifetime risk of developing diabetes of approximately $40 \%$, and display insulin resistance $[8,20,21]$ that is associated with increased fasting plasma NEFA [8], increased intramyocellular lipid content [22] and mitochondrial dysfunction [23]. In line with other studies [8, 24], insulin sensitivity was negatively related to lipid metabolism variables (fasting triacylglycerol, LDL-cholesterol) and obesity (waist circumference, BMI) and to blood pressure and positively related to plasma HDL-cholesterol. Endogenous glucose production was not measured during the clamp test, thus insulin-mediated suppression of endogenous glucose production could not be determined. However, in a previous study we could not find differences in endogenous glucose production between participants with and without family history of diabetes during an isoglycaemic-hyperinsulinaemic clamp test [25].

\section{Beta cell function}

We found that a positive family history of type 2 diabetes and $M / I$ were both negative predictors of beta cell function in OGTT. In the present study, the beta cell function was decreased in response to oral glucose challenge in the offspring group and in those with normal insulin sensitivity (third $M / I$ quartile) when compared with evenly matched insulin-sensitive control groups. Furthermore, in the offspring with normal insulin sensitivity, signs of defective beta cell function in OGTT were even more pronounced than in the total offspring group, as not only the insulinogenic indices, but also the first hour and total insulin AUC and Cpeptide AUC were decreased. On the other hand, the differences in insulin secretion after oral glucose challenge could, in part, be attributed to effects of gut incretins, as relatives of type 2 diabetic patients show abnormal postprandial secretion patterns of glucose-dependent insulinotropic polypeptide [26].

Beta cell function can be assessed with several methods, such as the hyperglycaemic-hyperinsulinaemic clamp [27], the OGTT [18] or the IVGTT [18]. None of them is, however, an established gold standard and every test has advantages and limitations [28]. We have chosen OGTTbased indices of beta cell function because they are widely used and have a further value as they include possible incretin effects. From our study, it appears that the OGTTbased measures of beta cell function could detect subclinical beta cell defects, even in insulin-sensitive non-diabetic offspring of patients with type 2 diabetes.

A recent study in the RISC cohort investigating the associations between novel type 2 diabetes susceptibility gene loci found that the diabetes-risk alleles for CDKAL1, HHEX, IDE and TCF7L2 were associated with a decrease in beta cell function in non-diabetic individuals in an additive manner [29]. It is of note that the third $M / I$ quartile of the offspring group was well matched with the two control groups in terms of anthropometric characteristics, insulin sensitivity and lipid profiles, thereby ruling out the effects of glucolipotoxicity on the beta cell. Nevertheless, insulin secretion was impaired in the third $M / I$ quartile offspring group, underlining an inherent beta cell defect. Thus, our study provides additional evidence that beta cell defects could be inherited, possibly independently of insulin resistance.

Beta cell dysfunction is present in the offspring of type 2 diabetes patients after oral glucose challenge. As beta cell dysfunction still occurred in the offspring subgroup without insulin resistance, it appears that deficient insulin release is not necessarily linked to insulin resistance, but is the major pathophysiological feature in individuals likely to develop type 2 diabetes. Further preventive strategies may be necessary for this group.

\section{Conclusion}

In our study, the offspring of type 2 diabetes patients had both insulin resistance and beta cell dysfunction in response to oral glucose challenge. This beta cell impairment was detected also in the offspring of type 2 diabetes patients without insulin resistance, suggesting beta cell dysfunction is a major defect in the offspring of individuals with type 2 diabetes.

Acknowledgements The European Group for the Study of Insulin Resistance RISC study is partly supported by EU grant QLG1-CT2001-01252. Additional support has been provided by AstraZeneca (Sweden). The European Group for the Study of Insulin Resistance is supported by Merck Santé, France.

Duality of interest The authors declare that there is no duality of interest associated with this manuscript.

\section{References}

1. Martin BC, Warram JH, Krolewski AS, Bergman RN, Soeldner JS, Kahn CR (1992) Role of glucose and insulin resistance in development of type 2 diabetes mellitus: results of a 25 -year follow-up study. Lancet 340:925-929

2. Warram JH, Martin BC, Krolewski AS, Soeldner JS, Kahn CR (1990) Slow glucose removal rate and hyperinsulinemia precede the development of type II diabetes in the offspring of diabetic parents. Ann Intern Med 113:909-915

3. Turner RC, Mathews DR, Holman RR, Peto J (1982) Relative contributions of insulin deficiency and insulin resistance in maturity-onset diabetes. Lancet 1:596-598

4. Reaven GM (1988) Banting lecture 1988. Role of insulin resistance in human disease. Diabetes 37:1595-1607 
5. Ferrannini E, Balkau B, Coppack SW et al (2007) Insulin resistance, insulin response, and obesity as indicators of metabolic risk. J Clin Endocrinol Metab 92:2885-2892

6. Ferrannini E (1998) Insulin resistance vs insulin deficiency in non-insulin-dependent diabetes mellitus: problems and prospects. Endocr Rev 19:477-490

7. Anderwald C, Bernroider E, Krssak M et al (2002) Effects of insulin treatment in type 2 diabetic patients on intracellular lipid content in liver and skeletal muscle. Diabetes 51:3025-3032

8. Perseghin G, Ghosh S, Gerow K, Shulman GI (1997) Metabolic defects in lean nondiabetic offspring of NIDDM parents: a crosssectional study. Diabetes 46:1001-1009

9. Kahn SE (2003) The relative contributions of insulin resistance and beta-cell dysfunction to the pathophysiology of type 2 diabetes. Diabetologia 46:3-19

10. Ahren B, Pacini G (2004) Importance of quantifying insulin secretion in relation to insulin sensitivity to accurately assess beta cell function in clinical studies. Eur J Endocrinol 150:97-104

11. Wallace TM, Levy JC, Matthews DR (2004) Use and abuse of HOMA modeling. Diabetes Care 27:1487-1495

12. Hills SA, Balkau B, Coppack SW et al (2004) The EGIR-RISC STUDY (The European group for the study of insulin resistance: relationship between insulin sensitivity and cardiovascular disease risk): I. Methodology and objectives. Diabetologia 47:566-570

13. Kozakova M, Palombo C, Paterni M et al (2008) Body composition and common carotid artery remodeling in a healthy population. J Clin Endocrinol Metab 93:3325-3332

14. Anderwald C, Anderwald-Stadler M, Promintzer M et al (2007) The Clamp-Like Index: a novel, highly sensitive insulin sensitivity index to calculate hyperinsulinemic clamp glucose infusion rates from oral glucose tolerance test in nondiabetic humans. Diabetes Care 30:2374-2380

15. Stadler M, Anderwald C, Karer T et al (2006) Increased plasma amylin in type 1 diabetic patients after kidney and pancreas transplantation: a sign of impaired beta-cell function? Diabetes Care 29:1031-1038

16. Anderwald-Stadler M, Krebs M, Promintzer M et al (2007) Plasma obestatin is lower at fasting and not suppressed by insulin in insulin-resistant humans. Am J Physiol Endocrinol Metab 293: E1393-E1398

17. Promintzer M, Krebs M, Todoric J et al (2007) Insulin resistance is unrelated to circulating retinol binding protein and protein $\mathrm{C}$ inhibitor. J Clin Endocrinol Metab Nov 92:4306-4312
18. Tura A, Kautzky-Willer A, Pacini G (2006) Insulinogenic indices from insulin and C-peptide: comparison of beta-cell function from OGTT and IVGTT. Diabetes Res Clin Pract 72:298-301

19. Stadler M, Auinger M, Anderwald C et al (2006) Long-term mortality and incidence of renal dialysis and transplantation in type 1 diabetes mellitus. J Clin Endocrinol Metab 91:3814-3820

20. Vauhkonen I, Niskanen L, Vanninen E, Kainulainen S, Uusitupa M, Laakso M (1998) Defects in insulin secretion and insulin action in non-insulin-dependent diabetes mellitus are inherited. Metabolic studies on offspring of diabetic probands. J Clin Invest 101:86-96

21. Jacob S, Machann J, Rett K et al (1999) Association of increased intramyocellular lipid content with insulin resistance in lean nondiabetic offspring of type 2 diabetic subjects. Diabetes 48:1113-1119

22. Perseghin G, Scifo P, de Cobelli F et al (1999) Intramyocellular triglyceride content is a determinant of in vivo insulin resistance in humans: a $1 \mathrm{H}-13 \mathrm{C}$ nuclear magnetic resonance spectroscopy assessment in offspring of type 2 diabetic parents. Diabetes 48:1600-1606

23. Petersen KF, Dufour S, Befroy D, Garcia R, Shulman GI (2004) Impaired mitochondrial activity in the insulin-resistant offspring of patients with type 2 diabetes. N Engl J Med 350:664-671

24. Psyrogiannis A, Habeos I, Kyriazopoulou V (2003) Insulin sensitivity and $\mathrm{Lp}$ (alpha) concentrations in normoglycemic offspring of type 2 diabetic parents. Lipids Health Dis 2:8

25. Anderwald C, Pfeiler G, Nowotny P et al (2008) Glucose turnover and intima media thickness of internal carotid artery in type 2 diabetes offspring. Eur J Clin Invest 38:227-237

26. Nyholm B, Walker M, Gravholt CH et al (1999) Twenty-four-hour insulin secretion rates, circulating concentrations of fuel substrates and gut incretin hormones in healthy offspring of Type II (noninsulin-dependent) diabetic parents: evidence of several aberrations. Diabetologia 42:1314-1324

27. Bacha F, Gungor N, Arslanian SA (2008) Measures of beta-cell function during the oral glucose tolerance test, liquid mixed-meal test, and hyperglycemic clamp test. J Pediatr 152:618-621

28. Pacini G, Mari A (2003) Methods for clinical assessment of insulin sensitivity and beta-cell function. Best Pract Res Clin Endocrinol Metab 17:305-322

29. Pascoe L, Frayling TM, Weedon MN et al (2008) Beta cell glucose sensitivity is decreased by $39 \%$ in non-diabetic individuals carrying multiple diabetes-risk alleles compared with those with no risk alleles. Diabetologia 51:1989-1992 